\title{
Lessons to be learned from bankruptcy filings in public-private partnership (PPP) projects in the United States
}

\begin{abstract}
Adequate infrastructure is the foundation of thriving economies worldwide. With a growing call for increased infrastructure spending in the US, experts have touted publicprivate partnerships (PPPs) as one way to meet the nation's infrastructure needs. The rationale behind these partnerships is to share risks and harness the strengths of the private and public sector to deliver much needed infrastructure for the general public. However, these calls have not been received well due to past failures of PPP projects, especially in the transportation sector. Since 2000, several PPP project companies have filed for bankruptcy protection at a point in time during the operational phase which have led to losses for investors. This paper focuses on studying the common themes across such projects in the US. The aim is to identify common pitfalls which can be avoided in future projects to ensure successful partnerships between the public and private sectors.
\end{abstract}

Keywords: infrastructure, transportation, public-private partnership, bankruptcy, finance, toll-roads
Volume 2 Issue 2 - 2017

\author{
Offei Adarkwa, ' Omar Smadi, ${ }^{2}$ Ahmad \\ Alhasan $^{3}$ \\ Center for Transportation Research \& Education (CTRE), lowa \\ State University, USA
}

Correspondence: Offei Adarkwa, Center for Transportation Research \& Education (CTRE), lowa State University, USA, CTRE,Ames, IA, Email adarkwa@udel.edu

Received: February 10, 2017| Published: March 01, 2017
Abbreviations: PPP, public private partnerships; FHWA, federal highway administration; TIFIA, transportation infrastructure finance and innovation act; GCI, global competitiveness index; ASCE, american society of civil engineers; TxDOT, texas department of transportation; ITRCC, indiana toll road concession company; SBX, southbay expressway; LVMC, las vegas monorail company

\section{Introduction}

Massive infrastructure investment has dominated news headlines in the past few years. Infrastructure in the United States has become a major issue due to its current state which may be inadequate to support the economy in the next few years. With the new administration calling for increased private sector participation in infrastructure development, it will be beneficial to assess previous public-private sector partnership (PPP) projects which have not been entirely successful to avoid repeating past mistakes that can cost taxpayers and investors millions of dollars.

Population growth and urbanization have led to an increasing need for infrastructure development around the world. ${ }^{1}$ In the US, increased investment in infrastructure has been one of the few issues which had bipartisan support for a long time. ${ }^{2}$ It is no surprise that the 2013 American Society of Civil Engineers (ASCE) Report Card for US infrastructure has been quoted multiple times by industry experts and other stakeholders advocating for increased spending on infrastructure. In the report, the nation's infrastructure was given an overall grade of $\mathrm{D}+$. This grade implied that America's infrastructure is in poor to fair condition with most of the infrastructure elements nearing the end of their service life. According to the report, the estimated investment needed by the year 2020 was $\$ 3.6$ trillion. ${ }^{3}$ In the 2015-2016 Global Competitiveness Index (GCI) Report, the US ranked $3^{\text {rd }}$ behind Switzerland and Singapore as the most competitive global economies. ${ }^{4}$ However, the US was ranked $11^{\text {th }}$ in terms of infrastructure, which represents one of the 12 pillars based on which the overall competitiveness of economies are assessed. Figure 1 shows the overall competitiveness rank and infrastructure rank for the top 5 most competitive economies from the 2015-2016 GCI report. This further emphasizes the country's infrastructure needs.

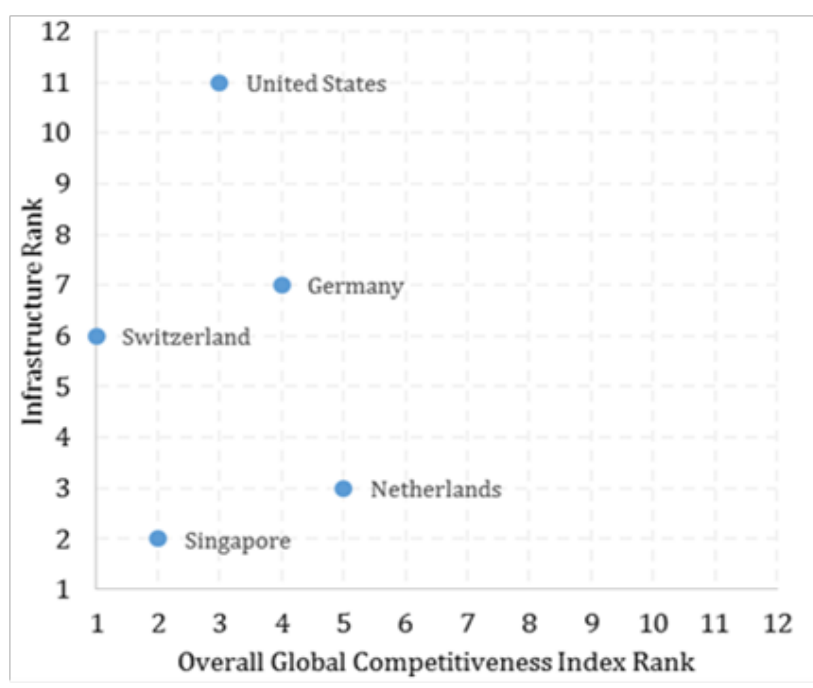

Figure I Comparing overall competitiveness rank with infrastructure rank for the top 5 most competitive economies ( $\mathrm{GCl} 2015-2016$ ).

A look at data from the Organization for Economic Co-operation and Development ${ }^{5}$ in Figure 2 sheds light on how much the 5 most competitive economies with the exception of Singapore spend on inland transportation infrastructure. Switzerland which was ranked as the most competitive economy (4) has spent a consistently higher percentage of Gross Domestic Product (GDP) on inland transportation infrastructure compared to the other 3 countries. The percentage of GDP spending on infrastructure was very similar for the Netherlands, Germany and the United States from 2011 to 2014. 
Despite, the equivalent proportion of GDP spending on transportation infrastructure, the condition of US infrastructure falls behind these 2 countries implying that addressing infrastructure needs involves more than just increased investment. There must be efficient allocation of resources in order to maximize benefits from infrastructure investment. This is one of the reasons why there has been a growing interest in public-private partnerships (PPPs). The rationale behind PPPs is to share risks and leverage the strengths of both the public and private sector to deliver much needed infrastructure for the general public. Officials in the current administration including Steve Mnuchin, ${ }^{6}$ Paul Ryan $^{7}$ \& Anthony Scaramucci ${ }^{8}$ have touted PPPs on various platforms as one of the ways to address America's infrastructure needs.

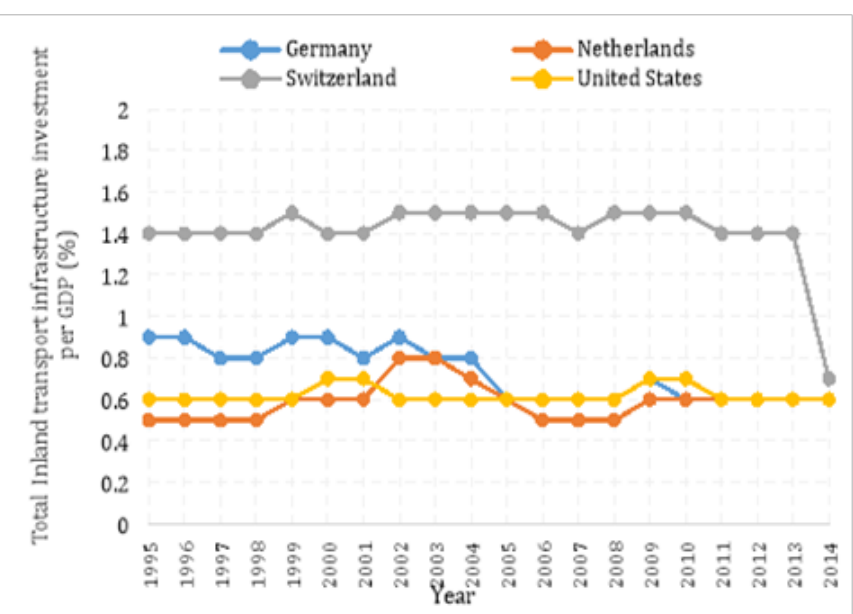

Figure 2 Total inland transportation investment as a percentage of GDP (OECD, 2016).

Recent calls for PPPs have not always been received positively in the US and it is important to recognize the basis for these concerns. PPPs have been met with skepticism by several stakeholders partly due to past failures. These involved a few project companies filing for bankruptcy during project implementation. Increased private sector participation in infrastructure investment may be inevitable in the future and as such there is a need to assess bankruptcy filings in past projects to avoid the common pitfalls moving forward. This paper focuses on US PPP projects in which the project company filed for bankruptcy at a point in time to determine if there are any common themes that can be addressed to ensure future success. This paper is divided into 4 main parts. After the introduction is the methodology section which details how PPP projects which filed for bankruptcy were selected and reviewed. The third section discusses the findings from the review and the fourth section highlights the key takeaways from this study.

\section{Methodology}

For this study, US PPP projects in the transportation sector in which the project companies filed for bankruptcy protection were considered. Focusing on the transportation sector reduces to an extent the high level of variability across projects. Common themes in these projects were identified using publicly-available information from the Federal Highway Administration (FHWA) and other sources.

\section{Discussion}

\section{Bankruptcy filings in US PPP projects}

I. A project company files for bankruptcy protection when it is unable to meet its debt obligations. A typical example of which may be a toll road company whose revenues are not enough to service its outstanding debt and operate the facility. The main goal of the federal bankruptcy laws is to give debtors a financial fresh start from burdensome debts. ${ }^{9}$ The six main types of bankruptcy cases are described briefly below:

II. Chapter 7: This involves an orderly court-supervised procedure in which the debtor's non-exempt assets are reduced to cash for distribution to creditors. Chapter 7 may be filed by companies who intend to terminate their enterprises and individuals who are unable to service their debt. ${ }^{10}$

III. Chapter 11: Typically filed by businesses who intend to continue operations and repay creditors at the same time through a court-approved reorganization plan. ${ }^{9}$ Reorganization may involve restructuring debt and also rescaling operations for profitability.

IV. Chapter 9: Similar to Chapter 11 except that only municipalities can file for this type of bankruptcy protection.

V. Chapter 12: Bankruptcy is for adjustment of debts of a family farmer or fisherman. Chapter 13 is for debtors with a regular income and Chapter 15 involves parties from more than one country. ${ }^{9}$

VI. When a concession company files for bankruptcy, there may be losses for taxpayers in cases where publicly funded debt are used and equity investors. ${ }^{11}$ In one such project, the TIFIA (Transportation Infrastructure Finance and Innovation Act) investment from the government was restructured as part of the bankruptcy reorganization plan at a value which $58 \%$ lower than the original investment. This meant that a $42 \%$ loss was imposed on federal taxpayers. ${ }^{12}$ Figure 3 is a typical cash flow waterfall illustrating how unlevered free cash flows from projects are distributed. Since equity investors are the last to receive payment in the event of a default, their potential losses in bad deals can never be overstated.

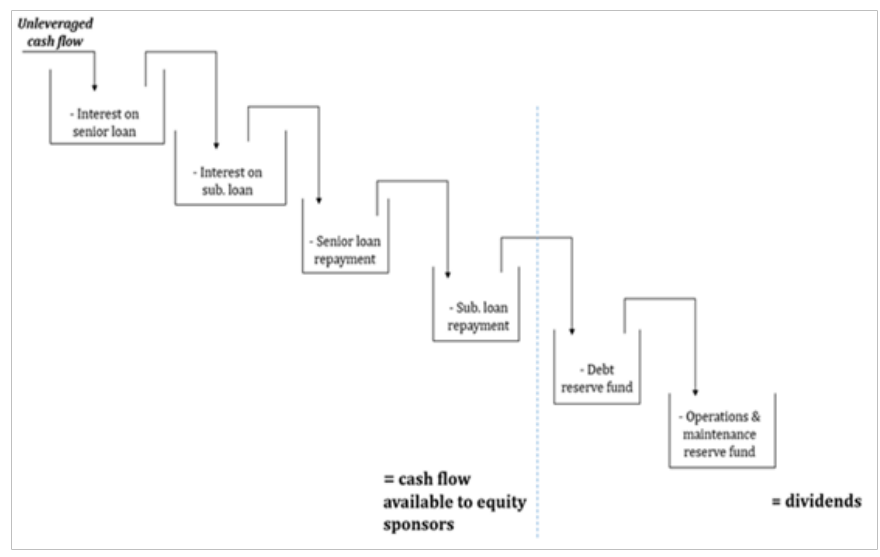

Figure 3 Typical cash flow waterfall.Adapted from. ${ }^{13}$

A higher proportion of US PPP projects that filed for bankruptcy were toll roads. This underscores the risky nature of such projects. ${ }^{13}$ Five notable PPP projects which filed for bankruptcy in the US are discussed further in this section. ${ }^{14}$

\section{SH I 30 (Segments 5-6)}

The Texas Department of Transportation (TxDOT) signed an agreement with SH 130 Concession Company to design, build, finance, operate and maintain a 40-mile extension of SH 130 
(Segments 5-6) in March 2007 under a 50-year concession. Segments 1-4 of SH 130 were delivered using a design-build comprehensive development agreement. Financing sources were from a combination of a senior loan worth $\$ 685.8 \mathrm{M}, \$ 430 \mathrm{M}$ TIFIA loan and $\$ 209.8 \mathrm{M}$ in equity. SH 130 Concession Company was a joint venture between Zachry American Infrastructure and Cintra. The project reached financial closure in March 2008. Construction commenced in April 2009 after which the \$1.3B project started service in November 2012 Revenues in the first few years after opening were more than $60 \%$ below forecasts. ${ }^{15} \mathrm{SH} 130$ Concession Company filed for Chapter 11 bankruptcy in March 2016. ${ }^{16}$

\section{Indiana toll road}

After a competitive bidding process, the lease for the 157-mile Indiana Toll Road was awarded to the Indiana Toll Road Concession Company (ITRCC) for $\$ 3.8 \mathrm{~B}$. This was $\$ 1 \mathrm{~B}$ higher than the other bids and exceeded the price expected by state officials. ${ }^{11}$ Financial closure for the deal was in June 2006. The financing sources were made up of $\$ 3.03 \mathrm{~B}$ senior loan and $\$ 374 \mathrm{M}$ apiece in equity from Cintra and Macquarie. The original lease agreement was over a period of 75 years. Despite annual increases in revenue, project debt rose from $\$ 3.4 \mathrm{~B}$ to almost $\$ 6.0 \mathrm{~B}$ in 2011 which may have been due to how the financing package for the deal was structured. ${ }^{17}$ In September 2014, ITRCC filed for Chapter 11 bankruptcy. ${ }^{18}$ IFM Investors took over the project in a renegotiated $\$ 5.725 \mathrm{~B}, 66$-year lease concession in May 2015 post Chapter 11 filing. ${ }^{19}$

\section{South bay expressway}

South Bay Expressway (SBX) which cost $\$ 658 \mathrm{M}$ is a 9.2-mile toll road extension of SR 125 from San Miguel Road in Bonita, California to SR 905 in Otay Mesa. Financial closure of the deal occurred in May 2003. Financing for the project which involved $\$ 140 \mathrm{M}$ in TIFIA loans and $\$ 340 \mathrm{M}$ in senior bank debt were both backed by toll revenues. Equity investment amounted to \$130M. In March 2010, SBX LP, the original project company, filed Chapter 11 bankruptcy. SBX LP was owned by Macquarie Infrastructure Partners and Macquarie 125 Holdings. The project started operations in November 2007. Filing was attributed to lower than expected revenues as well as financial burdens in the form of litigation costs in a case with the project contractor. The reorganization plan included conversion of the original project company SBX, LP to a Delaware limited liability company, South Bay Expressway, LLC. Restructuring of project debt was confirmed in April 2011. It is interesting to note that the state awarded the franchise for the toll road in 1991 but construction stalled for several years due to environmental permit issues which were resolved in $2003 .^{20,21}$

\section{Las vegas monorail}

The Las Vegas Monorail Company (LVMC) acquired the franchise for the expansion, operation and maintenance of the 3.9-mile monorail system linking major casinos and hotels in Las Vegas Nevada in 2000 The agreement was over a period of 50 years. The expanded monorail system opened to the public in July, 2004. The total project cost was $\$ 650 \mathrm{M}$ funded by tax-exempt revenue bonds backed by fares and advertising. In January 2010, LVMC filed for Chapter 11 bankruptcy. The bankruptcy plan was approved in 2012. The Las Vegas Monorail Company emerged from bankruptcy in 2012 with $98 \%$ reduction in debt and maintained its not-for-profit status. Revenues have grown in recent years. ${ }^{22,23}$

\section{South Carolina connector 2000}

The 16-mile Southern Connector toll road links I-385 with
I-85 south of Greenville, SC. The project, funded by $\$ 240 \mathrm{M}$ in tax-exempt toll revenue bonds issued in 1998 is a PPP agreement between Interwest Carolina Transportation Group, LLC and the South Carolina Department of Transportation (SCDOT) under a 50-year license. These two partnered to form the Connector 2000 Association, Inc. (C2A). Operations for the Southern Connector started in March $2001 .{ }^{24}$ Revenue fell short of forecasts due to slow development of land use in the surrounding area (24). C2A had $\$ 173.3 \mathrm{M}$ deficit at the end of 2009 and defaulted on some bonds in January. ${ }^{25} \mathrm{C} 2 \mathrm{~A}$ filed for Chapter 9 bankruptcy in June 2010. The bankruptcy plan for reorganization was approved in August 2012. ${ }^{26}$

\section{Common themes}

A closer look at the projects listed above reveals the following common themes:

\section{Inaccurate traffic projections}

The most obvious trend across these projects is inaccurate traffic projections. Forecasting traffic volumes is fundamental to revenue estimation in PPP projects. In each of the above projects, actual traffic and revenue fell short of projections during project development. This led to the inability of project companies to service their debt over time. Past research on toll road forecasting performance for projects revealed optimism bias and large differences between predicted and actual revenues generated. A study of 100 toll road projects showed that actual traffic in the first year was between $86 \%$ below to $51 \%$ above predicted traffic volumes which signifies a very large range of error. ${ }^{27}$ Inaccurate projections can also affect how public agencies may quantify risk compensation. ${ }^{28}$ Traffic forecast errors stems from private sector companies desiring to secure deals with overlyoptimistic predictions or the result of modeling flaws. ${ }^{29}$ In 2014, SH 130 had 16,400 transactions per day which was still 30\% below initial projections. ${ }^{30}$ The LVMC has never achieved close to the forecast annual minimum of 20 million riders. ${ }^{31}$ Total ridership for LVMC in 2015 was about 5 million. ${ }^{32}$

\section{Timing}

The recession in 2007 and 2008 has been cited as the reason why actual traffic failed to meet projections in almost all the above projects. For SH 130, a statement issued by the concession company cited the 'lingering effects of the recession' to have reduced traffic volumes during the first few years after opening. ${ }^{33}$ For the Las Vegas Monorail, the economic downturn was also cited as being part of the reason for lower than expected traffic in the city. ${ }^{34}$ Significant drops in truck traffic also led to ITRCC's financial strain. Figure 2 which shows the total highway vehicle-miles travelled from the year 2000 to 2014 supports the theory that the timing of these deals coinciding with the financial crisis had a part to play in lower than expected revenues. In Figure 4, a sharp decline of about $2 \%$ in total highway vehicle miles can be observed between 2007 and 2008. Figure 5 also shows all five projects filed for bankruptcy after 2008 which confirms the earlier assumption that the financial crisis had an effect on revenues. Interestingly, 3 out of the five projects filed for bankruptcy in 2010. In addition to several other factors, the economic crisis played a major part in making these projects financially unsustainable. ${ }^{35}$

Apart from these two common themes, it must be stated that there were several project-specific factors that led to project companies filing for bankruptcy. For example, litigation related to claims by the contractor for the SBX project increased financial burden on the project company in addition to lower than expected revenues. This 
made SBX LP unable to meet its debt obligations. In the case of the Indiana Toll Road, studies conclude that the ITRCC may have overpaid for the asset. One valuation model estimated a present value for the asset at $50 \%$ of the winning bid value from ITRCC which was \$1B higher than the other bids. ${ }^{11}$ The doubling of project debt for the Indiana Toll Road was also attributed to declining interest rates which led to losses on the interest rate swaps used in the project's financial package. ${ }^{17}$

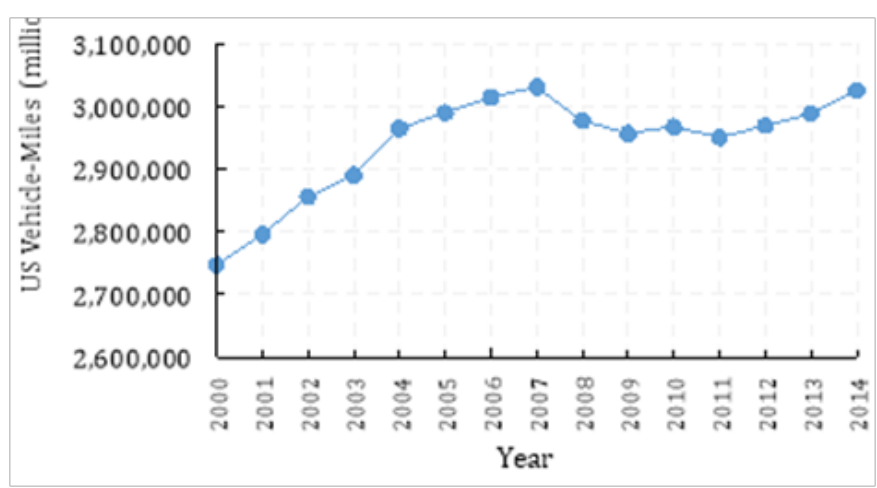

Figure 4 US Vehicle-miles travelled from 2000 to 2014.35

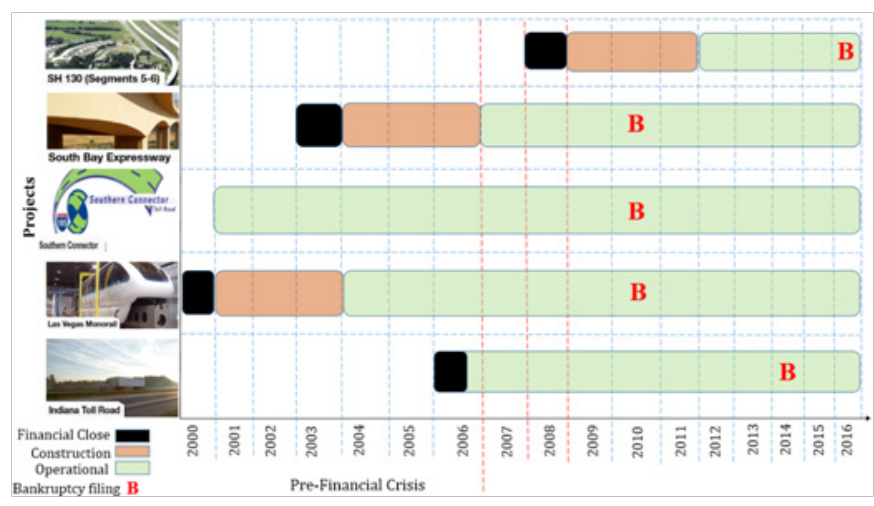

Figure 5 Year of service commencement, construction, operations \& bankruptcy filing for projects considered (FHWA IPD Project Profiles).

\section{Conclusion}

At the aggregate level, it is evident that the leading cause of the bankruptcies in PPP projects is the overly-optimistic traffic projections. The 2007-2008 economic crisis also had an impact across all projects and is often cited as a contributing factor to the subpar performance of these projects. Since no two projects are the same given differences in geographical location, timing, project counterparties and structure of deals, future studies will focus on detailed investigations on individual projects.

For all the cases discussed in the paper, the projects continue functioning while debt restructuring is in process. This is good for the public who use the infrastructure but often affects the bottom-line of lenders and equity investors significantly. An example of this is in June 2009 when Macquarie had to write down its investment in SBX to zero. Infrastructure investors, especially pension funds who have long-term obligations must perform adequate due diligence before investing in toll roads and other infrastructure assets in which they are exposed to demand risks. Government agencies and lenders must build capacity to verify traffic projections from potential partners during the bidding stage. The public sector must be wary of project participants who are eager to close deals and so inflate revenue projections in their bids. Such companies may be motivated by management fees based on the amount of assets under management. Minimizing operating costs should also be paramount to project companies seeking to gain profitability in their operations. In order to achieve this, project companies must invest in efficient toll-collection technologies. In addition, strategic branding must also be a priority in a PPP project if it is to gain support and patronage from the public. PPP projects are still generally viewed with skepticism and so proper branding and publicity can elicit favorable response from users. Finally, deal structuring must be flexible to accommodate future changes in demand as a result of unexpected economic events. Future research will focus on examining individual projects to identify specific causes of the project company's inability to service debt.

\section{Acknowledgements}

None.

\section{Conflict of interest}

The author declares no conflict of interest.

\section{References}

1. Mann P. The Growing Need for Infrastructure Investment. International Banker. 2017.

2. Adarkwa O, Radovic M. Taking a Closer Look at Infrastructure Investment. Civil Data Analytics. 2016.

3. ASCE. 2013 Report Card for America's Infrastructure. 2013.

4. WEF. Competitiveness Rankings. World Economic Forum's Global Competitiveness Index. 2016.

5. OECD. Transport infrastructure investment and maintenance spending Investment in inland transport infrastructure as a percentage of GDP. OECD-International Transport Forum. 2016.

6. NATSO. Mnuchin Reiterates President -Elect's Support for Infrastructure. 2017.

7. Zanona M. Ryan offers picture of public-private spending in Trump's infrastructure plan. The Hill; 2017.

8. Blodget H. Trump adviser Scaramucci nails the problem with the economy-and suggests it will take 5-15 years to fix. Markets Insider. 2017.

9. US Courts. Process - Bankruptcy Basics. United States Courts. 2017.

10. Chapter 7 Bankruptcy - Liquidation under the Bankruptcy Code. IRS. 2017.

11. Bondy D. Optimizing Public-Private Partnerships: A Case Study in US Transportation Infrastructure. Joseph Wharton Research Scholars. 2016.

12. CBO. Using Public-Private Partnerships to Carry Out Highway Projects. A CBO Study. Congress of the United States Congressional Budget Office. 2012

13. Gatti S. Project Finance in Theory and Practice-Designing, Structuring and Financing Private and Public Projects. Elsevier; 2008.

14. Gregerson J. Hit or Miss: Bankruptcies Taking Toll on P3 Projects. Built worlds. 2016.

15. Build America Bureau. SH 130 (Segments 5 -6), Austin, TX-Project Overview. United States Dept. of Transportation Build America Bureau. 2015.

16. FHWA. Project Profiles-SH 130 (Segments 5-6). US Department of Transportation Federal Highway Administration. 2017. 
17. Bipartisan Policy Center. Infrastructure Case Study: Indiana Toll Road. 2016 .

18. Brosher B. How the Toll Road Bankruptcy Could Impact Indiana. Indiana Public Media News; 2014.

19. FHWA. Project Profiles - Indiana Toll Road. US Department of Transportation Federal Highway Administration. 2017.

20. Saskal R. California P3 Files Chapter 11. The Bond Buyer. 2010.

21. FHWA. Project Profile - South Bay Expressway. US Department of Transportation Federal Highway Administration. 2017.

22. Marroquin A. RTC to examine proposal to extend monorail. Las Vegas Review-Journal. 2016.

23. FHWA. Project Profile - Las Vegas Monorail. US Department of Transportation Federal Highway Administration. 2017.

24. Stantec. Southern Connector Toll Rate Study. Stantec Consulting Services. 2015.

25. Stempel J. S Carolina toll road in rare Chapter 9 bankruptcy. Reuters. 2010 .

26. FHWA. Project Profile-Southern Connector. 2017.
27. Bain R. Error and optimism bias in toll road traffic forecasts. Transportation. 2009.

28. Prozzi J, Flanagan K, Loftus -Otway L, et al. Actual vs. Forecasted Toll Usage: A Case Study Review. Center for Transportation Research, The University of Texas at Austin; 2009.

29. Rouhani OM. Revenue Risk Mitigation Options for Toll Roads. USA: McGill University; 2015.

30. Wear B Owner of southern section of Texas 130 files for bankruptcy. My states man. 2016.

31. Jedlicka D. Gaming Opportunities, Attractions and Monorail Ridership in Las Vegas. Center for Gaming Research - Occasional Paper Series. USA: University Libraries, University of Nevada; 2013.

32. Las Vegas Monorail. 2015 Ridership and Revenue Data. 2017.

33. SH 130. SH130 Concession Company Files for Chapter 11. SH 130 Concession Co, LLC; 2016.

34. Hansen KB. Las Vegas Monorail files for bankruptcy protection. Las Vegas Sun; 2010.

35. Bureau of Transportation Statistics. US Vehicle -Miles. National Transportation Statistics Table 1 -35. 2016. 